\title{
Energy Generation from Biomass in Tanzania Impacts and Challenges: An Overview
}

\author{
Dr. Arthur Mngoma Omari \\ Electrical and Power Engineering, \\ Mbeya University of Science and \\ Technology Mbeya, Tanzania
}

\author{
Mrs. Janet Tesha \\ Electrical and power engineering \\ Mbeya University of Science and \\ Technology Mbeya, Tanzania
}

\author{
Mr. Halidini Sarakikya \\ PhD Student kenyatta University \\ Nairobi, Kenya
}

\begin{abstract}
At present, much attention is on how to find the appropriate and proper renewable energy source which will offer sufficient energy output to replace the use of conventional fossil fuel sources. The energy stored in various biomasses available in Tanzania is huge and can provide sufficient energy to supply the rural societies. The energy crises facing rural societies in Tanzania can be solved and minimized by proper harnessing the substantial biomass available in the Country. The energy conversion process from the biomass and the type of energy required plays a vital role in identifying the type of biomass required in the process. The objective of this paper is to address different types of energy from various biomass sources, highlight the challenges and impact of each type.
\end{abstract}

Keywords-Biomass, Bio-fuel, Cow dung, Cassava, Sugarcane

\section{INTRODUCTION}

Biomass is any plant or animal-derived organic matter available on a renewable basis which can be used for the generation of various forms of energy [1]. There are many forms of biomass, but it can be classified according to its end use biomass required such as fuel biomass, feed biomass, organic fertilizer, and/or chemical biomass [2]. The method of the biomass conversion process will depend on the type of biomass. The byproducts of biomass have produced urban MSW [3] which caused environmental degradation in most cities of Africa due to poor solid waste management. It is further emphasized that energy recovery from these resources and other MSW has the potential to alter this situation and hence converting what would otherwise be waste into a highvalue product [1].

For the proper utilization of biomass resources, it should be therefore converted to energy which can lessen a substantial amount of the country's demand. Plants and other forest residues can be converted into energy in the form of heat or Electricity through the incineration process [4]. The production of biofuel such as ethanol can be done by the fermenting a plant matter and then burnt alone or in combination with other conventional fuels for purposes such as heat generation for cooking and provision of a mechanical drive for the generation of electricity [5-8]. Ethanol is a grain alcohol that can be blended with gasoline to be used in motor vehicles, tractors, and combined harvesters. The decomposition of organic matter by microbial action produces biogas which can be used for cooking [9-11].

In the conversion processes, environmental, economic, and social challenges cannot be ignored [12]. When biomass is burned it produces the same emissions as those given out when fossil fuel burned [13]. Growing biomass captures carbon dioxide out of the air so that the net contribution to global atmospheric carbon dioxide levels is lessened [1]. The process of growing biomass is subject to the same environmental concerns as any kind of agriculture since it uses a large amount of land, fertilizers, and pesticides for costeffective growth [14]. Biomass which originates from a byproduct of agriculture has some advantages compared to others even though this kind of biomass is returned to the soil as a fertilizer [15].

The production of biomass will keep the society busy in a way that will participate in many production activities, and hence learn waste management [16]. On the other hand biomass, production creates employment [17], generates income and energy services that would otherwise not be available, and therefore improve the standard of life for poor society [18, 19]. The aim of this paper is, therefore, to discuss biomass from cassava, sugarcane, rice husk, and cow dung for the production of fuel.

\section{FUEL BIOMASS FROM CASSAVA}

As an energy source, biomass can either be used directly via combustion to produce heat or indirectly after converting it to various forms of biofuels. Conversion of biomass to biofuel can be achieved by different methods such as thermal, biochemical, and Chemical [12, 20]. Fuel biomass consists of various chemical energy sources in the form of solid, liquid, and gaseous which is obtained when plants and animal materials are processed [21, 22]. When these fuels are readymade, they can be used alone or in combination with conventional fuels for heat and electricity generation. Ethanol is among the biomass liquid fuel, manufactured by microbial conversion through fermentation by three main stages, the conversion of biomass to sugar, fermentation of sugar to ethanol, and purification of the ethanol [23]. Other types of biomass fuels are such as biogas obtained from waste and putrefaction of plants and animal matter in lands and also biogas formed by the decomposition of organic matter through microbial actions [23, 24].

The bias towards cassava for this study is because of its huge availability throughout Tanzania. Cassava is cultivated and produced in all regions of Tanzania [25]. The main producing areas are Mwanza, Mtwara, Lindi, Shinyanga, Tanga, Ruvuma, Mara, Kigoma, Coast regions, and most regions in Zanzibar [26]. Cassava is an important subsistence food crop in Tanzania, especially in the semi-arid areas and sometimes considered as a famine reserve when cereals fail due to its 
drought tolerance [27, 28]. Cassava utilized as human food, starch making, livestock feed, and export [29]. Both roots and leaves of cassava are of major nutritional importance [30, 31] At present, the largest part of ethanol production in Tanzania is from petrochemicals, which has the undesirable effect of tasking the nation's crude reserve even more. Looking for the alternative such as cassava is, therefore, an appropriate opportunity [32]. This would have the desirable effect of not just reducing the dependence on petroleum fractions for the production of ethanol, but also create employment in the rural areas where cassava is cultivated $[32,33]$. The financial benefit to cassava farmers needs to be uplifted. Cassava has been used for the production of food in most parts of Tanzania, mainly "Ugali" and "Kisamvu". Cassava pieces are roasted and used with tea for breakfast. Using cassava for the production of ethanol will uplift the competition with other users. Globally it has been discussed that the share of biofuels has increased moderately, as well as the production of biomass yield and so there will be no great impact on demand [34]. The process will decrease the energy poverty but for poor developing countries where the production of biomass is still dormant the possible risk is that there will be less cassava for food and cost for cassava as food will overshoot than expected and the life for poor Tanzanian may be seriously interfered [35, 36].

Besides, as the use of cassava for the production of ethanol will no doubt increase the demand for cassava, may turn cassava into a very profitable cash crop than it is at present, and because of this, farmers may dispose of the cultivation of other crops and invest much of their times in it, disrupting food supply in the country. The Government is supposed to make sure that effort at encouraging a biofuel enterprise of this nature is done alongside measures that ensure it does not affect the cultivation of other food crops in the country. Such measures no doubt will include engaging farmers on the need to give equal interest to the cultivation of food crops the same with cassava, subsidizing food crop production by providing farmers with seedlings, farm implements, fertilizer, and finance to make them grow food crops equally.

However, in the process when biomass is converted into energy such as heat, it produces several emissions characteristic as those produced when using fossil. Regrown biomass removes carbon dioxide from the atmosphere, leaving nature unbiased [37], the greatest benefit from ethanol production using cassava enhances the reduction of the demand in fossil fuels [38]. The costs of extracting fossil fuels are higher as fossil fuel has to be extracted from the ground or underwater before it can be processed into a useful portion [39].

In comparison, considering the processes of extracting ethanol from cassava and petrochemicals from petroleum and then to ethanol, substantial energy savings could be implied by the former which also has the added benefit of being able to extend the longevity of the crude reserve. It is the fact that biomass in the form of ethanol represents stored energy that can be used both in generating electricity and can be used in other important sectors [40]. In either case, there will be more funds increased to the government in taxes on products. Moreover, petrochemical and pharmaceutical enterprises use ethanol, and a boost in its production no doubt will enhance activity in those areas of the economy, with more jobs and more money added to the economy in the Country.

\section{BIOMASS ENERGY FROM SUGARCANE}

It is a perennial tropical grass with tall stout jointed stems from which sugar is extracted [41]. When growing, sugarcane converts sunlight into chemical energy which stores inside the plant [2]. Each of the following main plant components contains approximately one-third of its stored energy [1].

A. Juice - The sweet liquid inside sugarcane stalks containing sucrose used to provide Sugar.

B. Bagasse - is the fibrous matter that remains after sugarcane is crushed to extract their Juice.

C. Straw - The tops and leaves of sugarcane stalks.

Sugarcane production in Tanzania is concentrated mainly in Morogoro, Kagera and Kilimanjaro regions. Currently, there are four main sugar estates in Tanzania including Kilombero and Mtibwa in Morogoro region, TPC in Kilimanjaro region, and Kagera in Kagera region with more than 35,000 hectares, Fig. 1 is the portion of sugar cane plantation at Mtibwa [42]. Almost all of the sugar produced in the country is for home consumption [43].

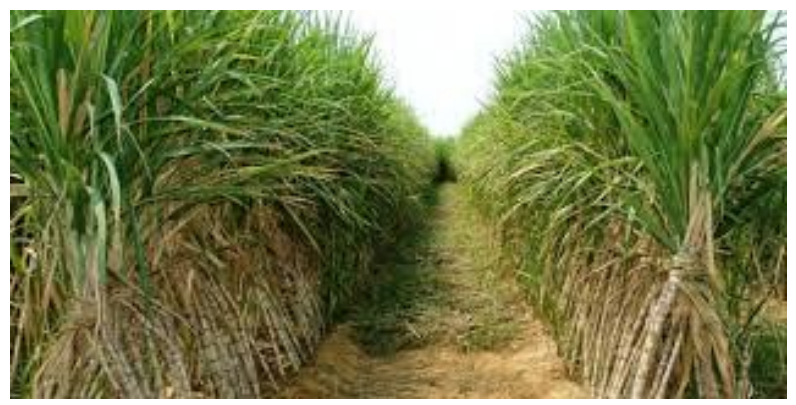

Figure 1: Sugarcane plantation at Mtibwa farm estate, Morogoro

Harvesting is done manually where the cane field is burnt to eliminate the straws. Another purpose of burning is to drive away snakes and potentially poisonous animals. This process leads to the destruction of one-third of the energy content of sugarcane [44]. The majority of emissions indeed come from the burning of the sugarcane field during the harvesting. It is estimated that straw can be burned alongside bagasse in highefficiency boilers to produce bioelectricity [3]. For every 100 tons of Sugarcane crushed, a sugar factory produces nearly 30 tons of wet Bagasse [45], which is used as a primary fuel source for Sugar Mills [46]. It produces sufficient heat and electrical energy to supply all the needs for typical Sugar mill, with energy to spare.

The sugarcane juice is a major source of both sugar and ethanol. Ethanol is commonly used to produce a biofuel called bioethanol. A most important benefit of bioethanol for the environment is its ability to be carbon neutral on a lifecycle basis [47]. The carbon dioxide emitted during its use is offset by the absorption from the atmosphere during expansion. Compared to gasoline, ethanol cuts greenhouse gases by at least $60 \%$ [48]. The production of biofuel ethanol can significantly replace the use of fossil fuel [49]. Ethanol is a grain alcohol that can be blended with gasoline and used in motor vehicles [50, 51]. However, it has been employed successfully as fuel for vehicles in its pure form [51]. 
Bioethanol has been used successfully in countries like Brazil, U. S, in Europe and many other developed countries [52]. Tanzania's dependence on fossil fuel can be reduced by the use of ethanol. Sugarcane ethanol is one more option for diversifying energy supplies and improving energy security. The Country has enormous uncultivated lands in regions which suits perfectly the farming of sugarcane. Some of the regions where sugarcane can be cultivated successfully include Kagera, Tanga, Pwani, Kilimanjaro, Arusha, Morogoro, Mbeya, Katavi, Mtwara, Lindi and Zanzibar. It is possible to increase the amount of land for sugarcane cultivation for biofuel production in Tanzania without decreasing food production.

Bioelectricity also has a low environmental impact $[53,54]$. If Mechanized farming is employed to remove the straw will help to reduce air pollution. The proper location of bioelectric plants will create employment opportunities in parts of the country where these production plants are located. Inclusively, it will reduce the high rate of rural to urban drift as well as contribute significantly to the socio-economic development of the country. The main problems that face the use of sugarcane as a source of energy are its usage for sugar production, its seasonal nature and decrease in biodiversity [55-57]. Other problems include the fact that sugarcane cultivation puts a high demand on the farm because of the use of heavy machinery [58]. Formulation of policies should be done to balance off the cultivation of sugarcane and other food crops to discourage farmers from sacrificing food crops for biofuel which will increase food prices around the Country.

\section{BIOMASS FROM RICE HUSK}

Rice husk is an agricultural residue available in many parts of the country. Tanzania has a large scale production of rice in East Africa [59]. Rice is one of the crops that have been largely used as staple food the second in consuming after maize. It is cultivated in many parts of Tanzania mainly in Morogoro, Tabora, Shinyanga, Mbeya, Kilimanjaro, Arusha, Manyara, Pwani, Mwanza, Rukwa, Geita and other areas with small scale production [60]. Rice husk dumps are increasing in alarming proportions in these regions. If the local production is increased, it will increase rice processing wastes such as rice straw and husk. Disposing and abandoning the rice husk dumps is urgently necessary because of the negative environmental impacts it possesses to the people and their surroundings. In an attempt to dispose of rice husk and rice straws (Fig. 2), most communities set the rice husk dumps on fire, unfortunately, a small amount of rice husk takes months to get burnt to ashes. Even when burnt to ashes, it is still an eyesore in the communities, especially during the rainy season.
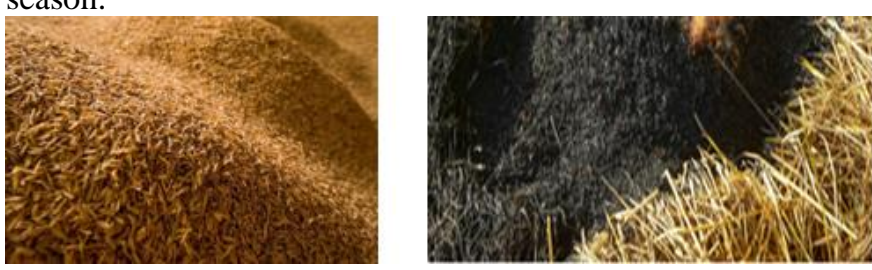

Figure 2: Rice husk and rice straws dump on open burning

Setting rice husk dumps on fire causes air pollution and accumulation of ash. Therefore, there is a need to urgently remove these dumps from communities. Rice husk which is the main by-product of rice processing has been identified as one of the potential biomass-based energy sources for power generation [61]. According to Ame-Oko et al., the calorific value contained in rice husk is about $13.64 \mathrm{MJ} / \mathrm{kg}$ and 15.84 $\mathrm{MJ} / \mathrm{kg}$ and therefore energy can be recovered from this resource [62]. Electricity generation can be achieved with the use of rice husk gasifier coupled with a modified internal combustion engine that drives a generator. Rice husk in gasifier can be converted into fuel gas under high temperature in an atmosphere of about $1 \%$ oxygen [63].

The synthesis gas (syngas) produced can be used directly in a gas-powered plant to generate electricity which will be used in the rice mill and the local population (Eric, 2008). The benefits of energy generation from rice husk include reducing the demand and increasing security of electricity supply, serving as a more purposeful way of disposing of the agricultural waste, rice husk ash which is the by-product of rice husk power plants can be used in the street and local road maintenance [64, 65], improving employment opportunities for the local population and reducing the environmental pollution caused by open burning of the rice husk.

\section{BIOMASS FROM ANIMAL WASTE - COW DUNG}

Animal waste pollutes the environment. The uncomfortable smell near the cattle and poultry farms testifies to this. It does not only affect the air quality but also pollutes the land and river, hence affecting aquatic life. Fig. 3 shows cow dung which is among the common animal waste from one of the Maasai homes. The Maasai is a tribe found in East Africa, Tanzania, and Kenya. Converting animal waste to energy, therefore, will not only provide alternative and renewable energy but will help clean up and provide a healthy environment. Animal wastes include poultry droppings, cow dung, etc. In this paper, cow dung is discussed.

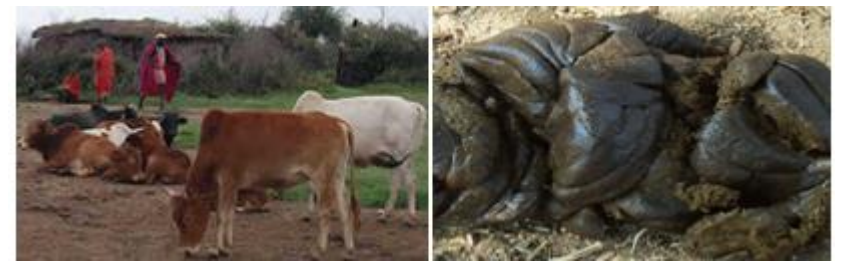

Figure 3: One of the Maasai home surrounded by a cow and a dung

The use of biogas technology to convert animal waste into energy helps improve the quality of life and health [66]. Biogas is produced either by anaerobic digestion or fermentation of biodegradable materials. The gas contains mainly of methane $(\mathrm{CH} 4)$ and carbon dioxide $(\mathrm{CO} 2)$ with a small amount of hydrogen sulfide and moisture [67]. The biogas mitigates a wide range of environmental pollutions, provides high-quality organic fertilizer, it serves for cooking or electricity generation thus reducing demand for fuel wood and charcoal for cooking. It improves water quality and mitigates greenhouse gas emissions. Cow dung is usually found in large farms in places where the cows are confined. Huge deposits of dung and other animal waste products are also available in abattoirs. These large abattoirs usually sited 
in the outskirts of every major town in Tanzania will guarantee the availability of large deposits of cow dung.

According to [1], a success story of Cows to Kilowatt is found in Ibadan, Nigeria. The project where a unique anaerobic fixed film reactor that treats slaughterhouse waste on-site, producing commercial quantities of organic fertilizer and captures the potent methane which can be used to generate electricity "at the rate of 1000 slaughtered per day, the plant would generate $3,600 \mathrm{KWh}$ of electricity" or used as cheap cooking gas. The project brings together three main points of sustainable development: economic efficiency, social collaboration, and protection of the environment. Economic efficiency, in the sense that it provides cheap gas, cleans organic fertilizer and employment for community members. Social collaboration in that the community learns about waste management, healthy living and protection of the environment from greenhouse gases and water pollution. Also, the provision of cheap cooking gas will decrease the use of fuel wood and charcoal for cooking, therefore, reducing deforestation. The advantage of biomass from cow dung is that cow dung is not seasonal. Cow dung does not reduce food supply rather it enhances healthy food production by the provision of organic fertilizer.

\section{CONCLUSION}

This paper has discussed in various ways biomass energy can be generated in Tanzania to supplement the energy from fossil fuel. These include biomass energy production from cassava, sugarcane, rice husks and cow dung. The major advantages of employing biomass from these resources include social collaboration, ease of maintenance, economic and energy security benefits as well as enhanced environmental friendliness over fossil fuel use. With increasing biomass development, farmers gain valuable new markets for their farm residues.

The main barrier is the localization of most of this biomass in different parts of the country. This can be overcome by localizing the plants that utilize each biomass resource for energy generation. To promote the mechanism and use of biomass, there is a need to advocate policies to strengthen energy institutions. In this regard, the identification of organization or agencies in central Government and Local Governments levels that will be charged with the responsibilities of ensuring the full implementation of these policies.

\section{REFERENCES}

[1] J. N. Ogwo, O. C. Dike, S. O. Mathew, and E. U. Akabuogu, "Overview of biomass energy production in Nigeria: implications and challenges," Asian J Nat Appl Sci, vol. 1, no. 4, pp. 46-51, 2012.

[2] S. Davis, W. Hay, and J. Pierce, "Biomass in the energy industry: An introduction," London (GB): BP plc, 2014.

[3] M. Kishimba, "Energy Recovery from municipal waste: making cities more productive and cleaner; converting an environmental and public health liability into a social economic and poverty alleviation asset," Dar es Salaam, Tanzania, 2008.

[4] A. M. Omari, B. N. Kichonge, J. R. Geofrey, K. N. Njau, and P. L. Mtui, "Potential of municipal solid waste as a renewable energy source - A case study of Arusha Tanzania," sustainable development, vol. 3, no. 1, pp. 1-9, 2014

[5] A. Evans, V. Strezov, and T. J. Evans, "Sustainability considerations for electricity generation from biomass," Renewable and sustainable energy reviews, vol. 14, no. 5, pp. 1419-1427, 2010 .
[6] L. Nunes, J. Matias, and J. Catalão, "Biomass in the generation of electricity in Portugal: A review," Renewable and Sustainable Energy Reviews, vol. 71, no. 1, pp. 373-378, 2017.

[7] M. N. A. M. Yusoff et al., "Comparative assessment of ethanol and isobutanol addition in gasoline on engine performance and exhaust emissions," Journal of Cleaner Production, vol. 190, no. 1, pp. 483-495, 2018.

[8] A. O. Hasan, H. Al-Rawashdeh, H. Ala'a, A. Abu-jrai, R. Ahmad, and J. Zeaiter, "Impact of changing combustion chamber geometry on emissions, and combustion characteristics of a single cylinder SI (spark ignition) engine fueled with ethanol/gasoline blends," Fuel, vol. 231, no. 1, pp. 197-203, 2018.

[9] E. D. Larson, "Biofuel production technologies: status, prospects and implications for trade and development," 2008: United Nations Conference on Trade and Development New York and Geneva.

[10] A. Khalid, M. Arshad, M. Anjum, T. Mahmood, and L. Dawson, "The anaerobic digestion of solid organic waste," Waste management, vol. 31, no. 8, pp. 1737-1744, 2011.

[11] H. Sarakikya and A. Kirobo, "Opportunities for Differen Agricultural and Forest Wastes as Sources of Energy in Tanzania," International Journal of Scientific Research Engineering \& Technology (IJSRET), vol. 7, no. 2, pp. 57-65, 2018.

[12] G. Boyle, Renewable energy (Renewable Energy). U.K: Oxford University Press, 2004, p. 456.

[13] J. T. Oladeji, "Agricultural and forestry wastes and opportunities for their use as an energy source in Nigeria-An overview," World Rural Obs, vol. 3, no. 1, pp. 107-112, 2011.

[14] S. Solinas, P. A. Deligios, L. Sulas, G. Carboni, A. Virdis, and L. Ledda, "A land-based approach for the environmental assessment of Mediterranean annual and perennial energy crops," European Journal of Agronomy, vol. 103, no. 1, pp. 63-72, 2019.

[15] E. Buonocore, A. Paletto, G. F. Russo, and P. P. Franzese, "Indicators of environmental performance to assess wood-based bioenergy production: A case study in Northern Italy," Journal of Cleaner Production, vol. 221, no. 1, pp. 242-248, 2019.

[16] E. W. Gabisa and S. H. Gheewala, "Potential of bio-energy production in Ethiopia based on available biomass residues," Biomass and bioenergy, vol. 111, no. -, pp. 77-87, 2018.

[17] K. Openshaw, "Biomass energy: employment generation and its contribution to poverty alleviation," Biomass and bioenergy, vol. 34, no. 3, pp. 365-378, 2010.

[18] Y. Du and K. Takeuchi, "Can climate mitigation help the poor? Measuring impacts of the CDM in rural China," Journal of Environmental Economics and Management, 2019

[19] E. Mboumboue and D. Njomo, "Biomass resources assessment and bioenergy generation for a clean and sustainable development in Cameroon," Biomass and bioenergy, vol. 118, no. 1, pp. 16-23, 2018.

[20] P. McKendry, "Energy production from biomass (part 2) conversion technologies," Bioresource technology, vol. 83, no. 1, pp. 47-54, 2002.

[21] L. Zhang, C. C. Xu, and P. Champagne, "Overview of recen advances in thermo-chemical conversion of biomass," Energy Conversion and Management, vol. 51, no. 5, pp. 969-982, 2010.

[22] B. B. Uzoejinwa, X. He, S. Wang, A. E.-F. Abomohra, Y. Hu, and Q. Wang, "Co-pyrolysis of biomass and waste plastics as a thermochemical conversion technology for high-grade biofuel production: Recent progress and future directions elsewhere worldwide," Energy conversion and management, vol. 163, no. 1, pp. 468-492, 2018.

[23] H. Zabed, J. Sahu, A. Suely, A. Boyce, and G. Faruq, "Bioethanol production from renewable sources: Current perspectives and technological progress," Renewable and Sustainable Energy Reviews, vol. 71, no. 1, pp. 475-501, 2017

[24] P. J. P. Zuurbier and J. van de Vooren, Sugarcane ethanol: Contributions to climate change mitigation and the environment. Wageningen Academic Pub, 2008.

[25] J. P. Legg and M. D. Raya, "Survey of cassava virus diseases in Tanzania," International Journal of Pest Management, vol. 44, no. 1, pp. 17-23, 1998/01/01 1998.

[26] M. Msabaha and B. Rwenyagira, "Cassava Production, Consumption and Research in the United Republic of Tanzania," Product Development for Root and Tuber Crops: Africa, vol. 3, no. -, p. 59, 1992 
[27] W. Howlett, G. Brubaker, N. Mlingi, and H. Rosling, "Konzo, an epidemic upper motor neuron disease studied in Tanzania," Brain, vol. 113, no. 1, pp. 223-235, 1990.

[28] H. Mongi, A. E. Majule, and J. G. Lyimo, "Vulnerability and adaptation of rain fed agriculture to climate change and variability in semi-arid Tanzania," African Journal of Environmental Science and Technology, vol. 4, no. 6, 2010.

[29] J. A. Montagnac, C. R. Davis, and S. A. Tanumihardjo, "Nutritional Value of Cassava for Use as a Staple Food and Recent Advances for Improvement," Comprehensive Reviews in Food Science and Food Safety, vol. 8, no. 3, pp. 181-194, 2009.

[30] R. Kapinga et al., "Status of cassava in Tanzania: implications for future research and development," in A Review of Cassava in Africa with Country Case Studies on Nigeria, Ghana, the United Republic of Tanzania, Uganda and Benin, Proceedings of the Validation Forum on the Global Cassava Development Strategy, 2005, vol. 2, p. 170e254.

[31] M. N. Omare, E. Nambiro, and G. B. Nkamleu, "Agricultura Growth, Poverty Reduction and Millennium Development Goals in Africa," in AAAE conference - 18-22 August, 2007 S. e. K. University, Ed., ed. Accra, Ghana, 2016.

[32] M. Zhang, L. Xie, Z. Yin, S. K. Khanal, and Q. Zhou, "Biorefinery approach for cassava-based industrial wastes: current status and opportunities," Bioresource technology, vol. 215, no. 1, pp. 50-62, 2016.

[33] L. K. Paine et al., "Some ecological and socio-economic considerations for biomass energy crop production," Biomass and Bioenergy, vol. 10, no. 4, pp. 231-242, 1996.

[34] A. Ajanovic, "Biofuels versus food production: Does biofuels production increase food prices?," Energy, vol. 36, no. 4, pp. 20702076, 2011.

[35] J. Karásek and J. Pojar, "Programme to reduce energy poverty in the Czech Republic," Energy Policy, vol. 115, no. 1, pp. 131-137, 2018.

[36] M. González-Eguino, "Energy poverty: An overview," Renewable and Sustainable Energy Reviews, vol. 47, no. 1, pp. 377-385, 2015.

[37] A. Valadkhani, J. Nguyen, and M. Bowden, "Pathways to reduce $\mathrm{CO} 2$ emissions as countries proceed through stages of economic development," Energy Policy, vol. 129, no. 1, pp. 268-278, 2019.

[38] A. Demirbas, "Importance of biomass energy sources for Turkey," Energy Policy, vol. 36, no. 2, pp. 834-842, 2008.

[39] C. Gokcol, B. Dursun, B. Alboyaci, and E. Sunan, "Importance of biomass energy as alternative to other sources in Turkey," Energy Policy, vol. 37, no. 2, pp. 424-431, 2009 .

[40] C. Anyanwu, C. Ibeto, S. Ezeoha, and N. Ogbuagu, "Sustainability of cassava (Manihot esculenta Crantz) as industrial feedstock, energy and food crop in Nigeria," Renewable energy, vol. 81, no. 1, pp. 745-752, 2015.

[41] L. Baucum, R. Rice, and T. Schueneman, "An overview of Florida sugarcane," University of Florida IFAS Extension document SS AGR-232, 2009

[42] A. J. P. Tarimo and Y. T. Takamura, "Sugarcane Production, Processing and Marketing in Tanzania," African Study Monographs, vol. 19, no. 1, pp. 1-11, 1998

[43] O. Nyangi, M. Wanjere, K. Egessa, and M. Wekesa, "Organizational capabilities and performance of sugar companies In Kenya," International Journal of Management Research \& Review, vol. 5, no. 8, pp. 845-863, 2015.

[44] T. d. F. Cardoso et al., "Technical and economic assessment of trash recovery in the sugarcane bioenergy production system," Scientia Agricola, vol. 70, no. 5, pp. 353-360, 2013.

[45] S. Solomon, "Sugarcane by-products based industries in India," Sugar Tech, vol. 13, no. 4, pp. 408-416, 2011

[46] R. L. Yadav and S. Solomon, "Potential of developing sugarcane by-product based industries in India," Sugar Tech, vol. 8, no. 1-2, pp. 104-111, 2006.

[47] D. Y. Leung, C. Y. Laura, G. C. Lam, H. Y. Kwok, and W. Cheng, "Bioethanol: Is It a Suitable Biofuel for Hong Kong for Reducing Its Vehicular Emissions and Carbon Footprint?," Energy Procedia, vol. 142 , no. 1, pp. 2892-2897, 2017

[48] P. Dwivedi et al., "Cost of abating greenhouse gas emissions with cellulosic ethanol," Environmental Science \& Technology, vol. 49, no. 4 , pp. 2512-2522, 2015
[49] A. Gupta and J. P. Verma, "Sustainable bio-ethanol production from agro-residues: a review," Renewable and sustainable energy reviews, vol. 41, no. 1, pp. 550-567, 2015.

[50] P. Iodice, A. Senatore, G. Langella, and A. Amoresano, "Effect of ethanol-gasoline blends on $\mathrm{CO}$ and $\mathrm{HC}$ emissions in last generation SI engines within the cold-start transient: An experimental investigation," Applied energy, vol. 179, no. 1, pp. 182-190, 2016

[51] M. Eyidogan, A. N. Ozsezen, M. Canakci, and A. Turkcan, "Impact of alcohol-gasoline fuel blends on the performance and combustion characteristics of an SI engine," Fuel, vol. 89, no. 10, pp. 2713-2720, 2010.

[52] Y. Su, P. Zhang, and Y. Su, "An overview of biofuels policies and industrialization in the major biofuel producing countries," Renewable and Sustainable Energy Reviews, vol. 50, no. 1, pp. 991-1003, 2015.

[53] V. Thomas, D. Choi, D. Luo, A. Okwo, and J. Wang, "Relation of biofuel to bioelectricity and agriculture: Food security, fuel security, and reducing greenhouse emissions," Chemical engineering research and design, vol. 87, no. 9, pp. 1140-1146, 2009.

[54] E. B. Sydney et al., "Current analysis and future perspective of reduction in worldwide greenhouse gases emissions by using first and second generation bioethanol in the transportation sector," Bioresource Technology Reports, p. 100234, 2019.

[55] L. Tran-Nguyen, K. Blanche, B. Egan, and K. Gibb, "Diversity of phytoplasmas in northern Australian sugarcane and other grasses," Plant Pathology, vol. 49, no. 6, pp. 666-679, 2000

[56] A. Beneduzi et al., "Diversity and plant growth promoting evaluation abilities of bacteria isolated from sugarcane cultivated in the South of Brazil," Applied Soil Ecology, vol. 63, no. 1, pp. 94104, 2013.

[57] L. A. Martinelli and S. Filoso, "Expansion of sugarcane ethano production in Brazil: environmental and social challenges," Ecological applications, vol. 18, no. 4, pp. 885-898, 2008.

[58] R. Singh, "Environmental consequences of agricultural development: a case study from the Green Revolution state of Haryana, India," Agriculture, ecosystems \& environment, vol. 82, no. $1-3$, pp. $97-103,2000$

[59] P. Rowhani, D. B. Lobell, M. Linderman, and N. Ramankutty, "Climate variability and crop production in Tanzania," Agricultural and forest meteorology, vol. 151, no. 4, pp. 449-460, 2011

[60] MAFSC, " National Rice Development Strategy," Ministry of Agriculture Food Security and Cooperative, Dar es Salaam, 2009, [Online]. Available: http://www.kilimo.go.tz.

[61] J. S. Lim, Z. A. Manan, S. R. W. Alwi, and H. Hashim, "A review on utilisation of biomass from rice industry as a source of renewable energy," Renewable and sustainable energy reviews, vol. 16, no. 5, pp. 3084-3094, 2012.

[62] A. Ame-Oko, B. Adegboye, and J. Tsado, "Analytical method to determine the potential of using rice husk for off grid electricity and heat generation," Nigerian Journal of Technology, vol. 37, no 1 , pp. 222-225, 2018

[63] J. Zhang and X. Zhang, "Thermochemical conversion of biomass into biofuels," in Biomass, Biopolymer-Based Materials, and Bioenergy, D. Verma, E. Fortunati, and X. Zhang, Eds. United Kingdom: Elsevier -Woodhead Publishing, 2019, pp. 327-368

[64] E. Oyetola and M. Abdullahi, "The use of rice husk ash in low-cost sandcrete block production," Leonardo Electronic Journal of Practices and Technologies, vol. 8, no. 1, pp. 58-70, 2006.

[65] B. S. Thomas, "Green concrete partially comprised of rice husk ash as a supplementary cementitious material-A comprehensive review," Renewable and Sustainable Energy Reviews, vol. 82, no. 1, pp. 3913-3923, 2018.

[66] A. Gómez, J. Zubizarreta, M. Rodrigues, C. Dopazo, and N. Fueyo, "Potential and cost of electricity generation from human and animal waste in Spain," Renewable Energy, vol. 35, no. 2, pp. 498$505,2010$.

[67] A. Molino, F. Nanna, Y. Ding, B. Bikson, and G. Braccio, "Biomethane production by anaerobic digestion of organic waste," Fuel, vol. 103, no. 1, pp. 1003-1009, 2013. 